\title{
INFLUENCE OF NANOCARBOXYLATES OF MICROELEMENTS ON RHIZOBIUM RADIOBACTER 204 GROWTH-REGULATING ACTIVITY
}

\author{
S. F. Kozar ${ }^{1}$, E. P. Symonenko ${ }^{1}$, V. O. Lynnyk ${ }^{2}$, V. H. Kaplunenko \\ ${ }^{1}$ Institute of Agricultural Microbiology and Agroindustrial Manufacture, NAAS \\ 97, Shevchenka str., Chernihiv, 14027, Ukraine; e-mail: neo_7676@bigmir.net \\ ${ }^{2}$ Ukrainian State Research Institute of Nanobiotechnologies and Resource Saving \\ 84, Malevycha str., Kyiv, 03150, Ukraine; e-mail: info@ndiresurs.gov.ua
}

The results of studies of the influence of nanocarboxylates (citrates) of microelements on Rhizobium radiobacter 204 growth-regulating activities are presented. It was found that increasing bacteria growth-regulating activity is achieved by the content of citrates of Zinc ( $\mathrm{Zn})$, Copper (Cu), Manganese (Mn), Iron (Fe) and Molybdenum (Mo) in culture medium in complex. It was shown that the use of nanocarboxylates of microelements while cultivating the investigated strain contributes to the increase of bacterial cells titre in a liquid culture medium by 1 billion/ $\mathrm{cm}^{3}$. It was revealed that the cultivation of $R$. radiobacter 204 under the action of citrates of microelements helps extent the exponential growth phase of these bacteria by 12 hours. According to the research results an optimized liquid culture medium was proposed for bacteria culturing.

Key words: Rhizobium radiobacter 204, nanocarboxylates of microelements, metal citrates, medium, culturing, optimization.

All living organisms, including bacteria, require for their development a number of chemical elements and compounds necessary for constructive metabolism, transportation systems operation, activation of enzymatic processes [1]. Some of these elements act as major $(\mathrm{Mg}, \mathrm{Ca}$, $\mathrm{K}, \mathrm{Fe})$, and other - minor ( $\mathrm{Zn}, \mathrm{Mn}, \mathrm{Mo}, \mathrm{Cu}, \mathrm{V}$, $\mathrm{Ni}, \mathrm{Co}$ ). The importance of both major and minor elements is determined by the fact that they are part of basic cellular metabolites, and thus take part in vital functions of organism [2-4].

The solubility of compounds of microelements in biological environments is quite high. At this their toxicity and biological compatibility with the organism as part of inorganic salts should be taken into account.

In Ukraine, a new form of compounds of microelements - nanocarboxylates (metal citrates) were created using nanotechnology techniques. Such a form of microelements was created by ablation of metallic granules in water, which is characterized by a much greater degree of digestibility and efficiency of interaction with biological objects than counterparts in the form of organic salts. As only water, carboxylic acid and metal source are used in the production, the created product is characterized by a high degree of environmental friendliness [5-6].

Today nanocarboxylates of microelements are widely used in agricultural production, particularly in livestock farming as antiseptics, stimulants of digestive processes of cattle, in healing of wounds and post-operative scarring in cattle [7]. In agriculture nanocarboxylates are used as microfertilizers for agricultural crops and have high stimulating impact on plant growth [8]. It is possible to explain the mechanism of action of these compounds through the fact that they activate useful soil microflora, which, in turn, stimulates and improves the nutrition of crops. But the impact of nanocarboxylates on the representatives of rhizosphere microorganisms, including nitrogen-fixing bacteria was studied fragmentarily.

Based on the above, the objective of our study was to investigate the features of di- 
azotrophs growth under the action of nanocarboxylates of microelements on the example of Rhizobium radiobacter 204 (bio-agent of microbial preparation Diazofit).

Materials and methods. Objects of study: $R$. radiobacter 204 [9], obtained from the collection of useful soil microorganisms of the Institute of Agricultural Microbiology and Agroindustrial Manufacture of NAAS, nanocarboxylates of microelements - Zinc (Zn), Copper $(\mathrm{Cu})$, Manganese $(\mathrm{Mn})$, Iron $(\mathrm{Fe})$ and Molybdenum (Mo). We express our sincere gratitude to the strain authors for a kindly provided object for the study.

Microelements were obtained by interaction of metal, metal oxide or metal hydroxide with citric acid in an aqueous colloidal solution with low (less than $10^{-6}$ wt. \%) content of chlor-, nitrate- and sulphate-ions. At this, metal, metal oxide or metal hydroxide stay in colloid solution in the form of metal, metal oxide or metal hydroxide nanoparticles obtained by ablation of metallic granules in water, and the ratio of the mass of metal carboxylate to nanoparticles mass amounts to at least $1000[5 ; 10]$.

To determine the growth-regulating activity of the studied strain under the influence of citrates of microelements the following ranges of their concentrations in the medium were taken as the basis for cultivation, that not inhibit microbiological processes, growth and development of bacteria, according to published data $[11 ; 12]$. However, the concentrations of nanocarboxylates in our study were expanded to such an extent $\left(\mathrm{mg} / \mathrm{dm}^{3}\right)$, Zinc $(\mathrm{Zn})-0.0005-1000$, Copper $(\mathrm{Cu})-0.03-100$, Manganese $(\mathrm{Mn})-$ 0.002-100, Iron $(\mathrm{Fe})-0.1-1000$, Molybdenum (Mo) - 0.001-10.

$R$. radiobacter 204 bacteria were grown under the conditions of periodic cultivation in microbiological rotator at $220 \mathrm{rpm}$ at the temperature of $28.0 \pm 2.0{ }^{\circ} \mathrm{C}$ for 72 hours in liquid pea culture medium [13]. Nanocarboxylates were added to culture medium before autoclaving.

Planning and conducting experiments on the study of metal citrate complexes impact on $R$. radiobacter 204 growth-regulating activity were performed according to the matrix of experiment planning at 5 factors and 5 levels of their interaction according to the scheme $5 \mathrm{i} 5 \mathrm{k}$ [14], microelements acted as factors, and their concentrations - as levels. The changes in the number of bacteria in the culture fluid were de- termined by generally accepted microbiological methods [15].

To study the dynamics of growth the bacteria were grown with such metal citrate concentration in the culture medium $\left(\mathrm{mg} / \mathrm{dm}^{3}\right)$, which most positively influenced their growth-regulating activity: Zinc $(\mathrm{Zn})-0.0005$, Copper $(\mathrm{Cu})-0.3$, Manganese $(\mathrm{Mn})-0.2$, Iron (Fe) - 10, Molybdenum (Mo) - 0.01. At this, during 72 hours of cultivation cells titre was calculated every 12 hours. The initial number of bacteria was $4 \cdot 10^{8}$ cells $/ \mathrm{cm}^{3}$ of culture medium. The obtained data made a curve of growth for periodic bacteria culture, on the basis of which the change of growth dynamics of studied strain was determined under the action of nanocarboxylates.

For the processing of experimental data computer software Statistica 10.0, and possibilities of electronic spreadsheets MS Excel were used.

Results and discussion. During the studies of the impact of nanocarboxylates on changing the number of bacteria in culture medium it was found that $R$. radiobacter 204 is able to withstand higher concentrations of studied compounds than previously described as for other microorganisms. It was defined that this strain does not reduce growth-regulating activity under the content of Copper $(\mathrm{Cu})$ in the medium at the concentration of $100 \mathrm{mg} / \mathrm{dm}^{3}$ (Fig. 1), Molybdenum (Mo) $-10 \mathrm{mg} / \mathrm{dm}^{3}$ (Fig. 2).

It was defined that the number of bacteria does not change under the concentration of Zinc (Zn) $-100 \mathrm{mg} / \mathrm{dm}^{3}$ (Fig. 3), Manganese $(\mathrm{Mn})-10 \mathrm{mg} / \mathrm{dm}^{3}$ (Fig. 4), Iron (Fe) $100 \mathrm{mg} / \mathrm{dm}^{3}$ (Fig. 5) in the culture medium. However, the number of $R$. radiobacter 204 bacteria is reduced by 2.32 billion $/ \mathrm{cm}^{3}$ (33\%) under the content of Zinc ( $\mathrm{Zn}$ ) in culture medium in the concentration of $1000 \mathrm{mg} / \mathrm{dm}^{3}$ (Fig. 3), by 1.32 billion $/ \mathrm{cm}^{3}$ (17\%) under the content of Manganese $(\mathrm{Mn})$ in the concentration of $50-100 \mathrm{mg} / \mathrm{dm}^{3}$ (Fig. 4), by 0.81 billion $/ \mathrm{cm}^{3}$ $(11.8 \%)$ under the content of Iron $(\mathrm{Fe})$ in the concentration of $1000 \mathrm{mg} / \mathrm{dm}^{3}$ (Fig. 5). There was no increase in the number of bacterial cells of the studied strain under the action of individual microelements.

Since, according to the obtained data, the increase in the number of bacteria in the culture fluid was not achieved under the content of any one nanocarboxylate in the culture medium, 


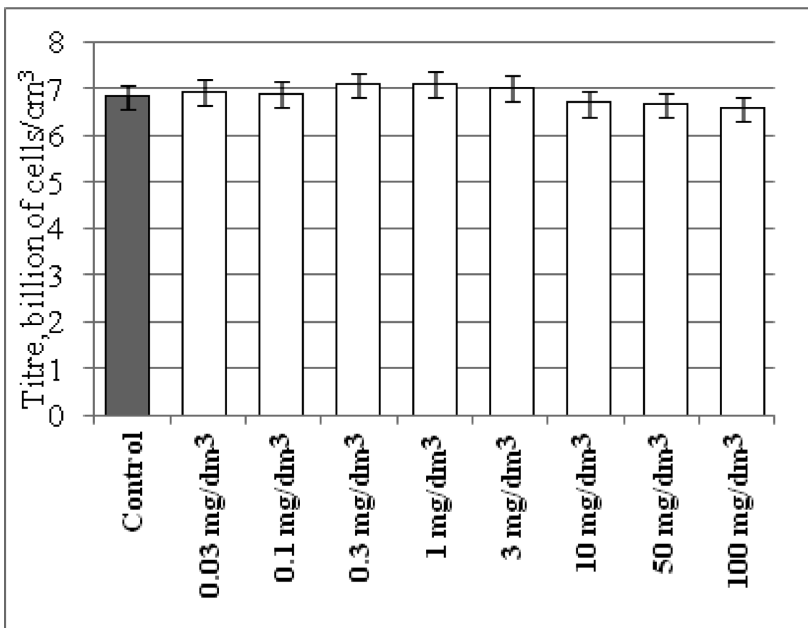

Fig. 1. Impact of Copper (Cu) nanocarboxylate on $R$. radiobacter 204 bacteria titre

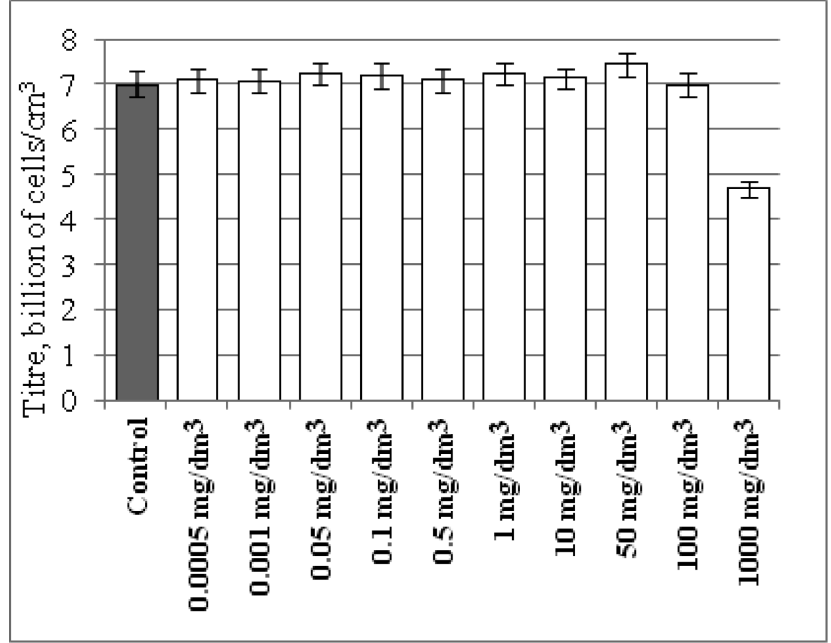

Fig. 3. Impact of Zinc (Zn) nanocarboxylate on $R$. radiobacter 204 bacteria titre

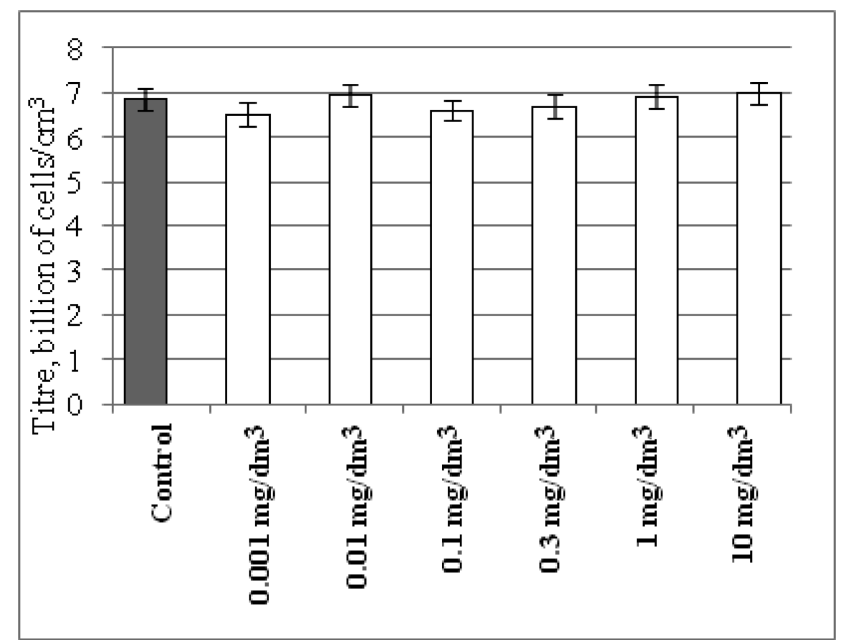

Fig. 2. Impact of Molybdenum (Mo) nanocarboxylate on $R$. radiobacter 204 bacteria

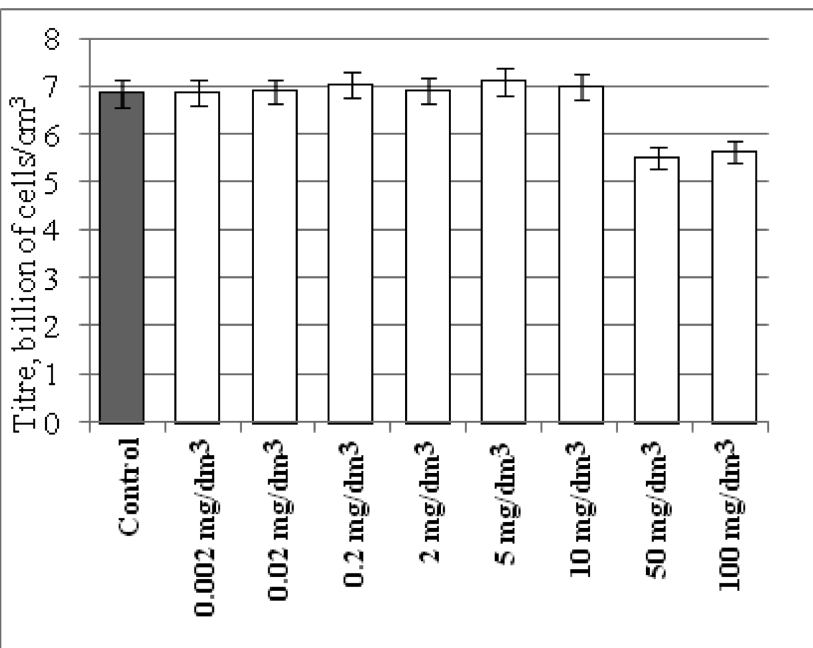

Fig. 4. Impact of Manganese (Mn) nanocarboxylate on $R$. radiobacter 204 bacteria titre

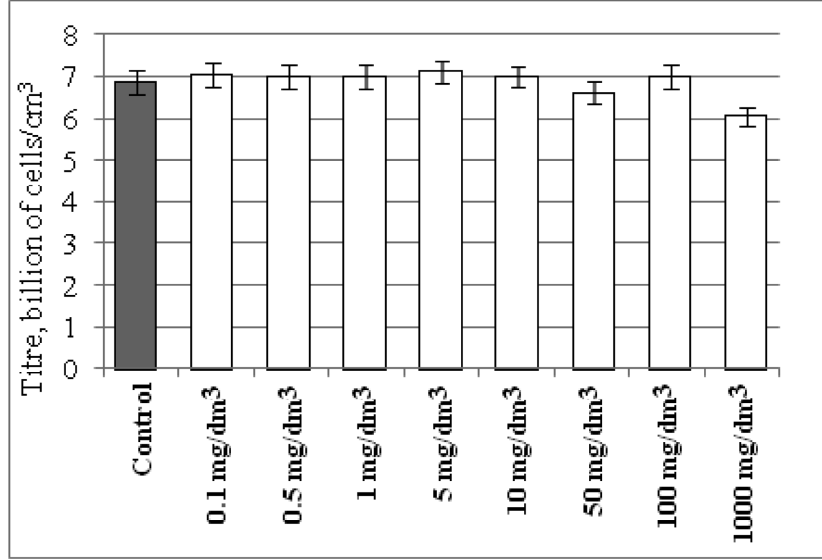

Fig. 5. Impact of Iron ( $\mathrm{Fe})$ nanocarboxylate on $R$. radiobacter 204 bacteria titre

then using the experiment planning matrix consisting of 5 factors and 5 levels of interaction, a number of options with different combinations of concentrations of studied elements in the culture medium were modelled (Table. 1).
The conducted studies under simulated options indicate that the combination of Zinc ( $\mathrm{Zn})$, Copper $(\mathrm{Cu})$, Manganese $(\mathrm{Mn})$, Iron $(\mathrm{Fe})$ and Molybdenum (Mo) nanocarboxylates in the culture medium made it possible to increase the 
Table 1. Impact of complexes of nanocarboxylates on the number of $R$. radiobacter 204 in a liquid medium

\begin{tabular}{|c|c|c|c|c|c|c|c|c|}
\hline \multirow[t]{2}{*}{ № } & \multicolumn{5}{|c|}{$\begin{array}{l}\text { Concentration of nanocarboxylate, } \\
\mathrm{mg} / \mathrm{dm}^{3} \text { of culture medium }\end{array}$} & \multirow{2}{*}{$\begin{array}{l}\text { Titre, } \\
\text { billion } / \mathrm{cm}^{3}\end{array}$} & \multirow{2}{*}{$\begin{array}{l} \pm \text { to control, } \\
\text { billion } / \mathrm{cm}^{3}\end{array}$} & \multirow{2}{*}{$\begin{array}{l}\text { Growth } \\
\text { in titre, } \%\end{array}$} \\
\hline & $\mathrm{Zn}$ & $\mathrm{Cu}$ & $\mathrm{Mn}$ & $\mathrm{Fe}$ & Mo & & & \\
\hline 1 & 0 & 0 & 0 & 0 & 0 & $6.47 \pm 0.26$ & 0 & 0 \\
\hline 2 & 0.0005 & 0.03 & 0.002 & 0.1 & 0.001 & $6.74 \pm 0.27$ & 0.27 & 4.2 \\
\hline 3 & 0.001 & 0.03 & 0.02 & 0.5 & 0.01 & $6.96 \pm 0.23$ & 0.49 & 7.6 \\
\hline 4 & 0.05 & 0.03 & 0.2 & 1 & 0.1 & $6.73 \pm 0.25$ & 0.26 & 4.1 \\
\hline 5 & 0.1 & 0.03 & 2 & 5 & 0.3 & $6.83 \pm 0.25$ & 0.36 & 5.5 \\
\hline 6 & 0.5 & 0.03 & 5 & 10 & 10 & $6.78 \pm 0.24$ & 0.31 & 4.8 \\
\hline 7 & 0.0005 & 0.1 & 0.02 & 1 & 0.3 & $7.04 \pm 0.27$ & 0.57 & 8.8 \\
\hline 8 & 0.001 & 0.1 & 0.2 & 5 & 1 & $7.10 \pm 0.27$ & 0.63 & 9.7 \\
\hline 9 & 0.05 & 0.1 & 2 & 10 & 0.001 & $6.88 \pm 0.26$ & 0.41 & 6.4 \\
\hline 10 & 0.1 & 0.1 & 5 & 0.1 & 0.01 & $6.92 \pm 0.25$ & 0.45 & 7.0 \\
\hline 11 & 0.5 & 0.1 & 0.002 & 0.5 & 0.1 & $7.11 \pm 0.25$ & 0.64 & 9.8 \\
\hline 12 & 0.0005 & 0.3 & 0.2 & 10 & 0.01 & $7.46 \pm 0.27$ & 0.99 & 15.4 \\
\hline 13 & 0.001 & 0.3 & 2 & 0.1 & 0.1 & $7.16 \pm 0.27$ & 0.69 & 10.7 \\
\hline 14 & 0.05 & 0.3 & 5 & 0.5 & 0.3 & $7.19 \pm 0.27$ & 0.72 & 11.1 \\
\hline 15 & 0.1 & 0.3 & 0.002 & 1 & 1 & $6.85 \pm 0.27$ & 0.38 & 5.9 \\
\hline 16 & 0.5 & 0.3 & 0.02 & 5 & 0.001 & $6.94 \pm 0.28$ & 0.47 & 7.3 \\
\hline 17 & 0.0005 & 1 & 2 & 0.5 & 1 & $7.07 \pm 0.27$ & 0.60 & 9.2 \\
\hline 18 & 0.001 & 1 & 5 & 1 & 0.001 & $7.15 \pm 0.26$ & 0.68 & 10.5 \\
\hline 19 & 0.05 & 1 & 0.002 & 5 & 0.01 & $6.78 \pm 0.27$ & 0.31 & 4.7 \\
\hline 20 & 0.1 & 1 & 0.02 & 10 & 0.1 & $6.88 \pm 0.26$ & 0.41 & 6.4 \\
\hline 21 & 0.5 & 1 & 0.2 & 0.1 & 0.3 & $6.60 \pm 0.27$ & 0.13 & 2.0 \\
\hline 22 & 0.0005 & 3 & 5 & 5 & 0.1 & $7.08 \pm 0.27$ & 0.61 & 9.4 \\
\hline 23 & 0.001 & 3 & 0.002 & 10 & 0.3 & $6.97 \pm 0.26$ & 0.50 & 7.7 \\
\hline 24 & 0.05 & 3 & 0.02 & 0.1 & 1 & $6.81 \pm 0.25$ & 0.34 & 5.2 \\
\hline 25 & 0.1 & 3 & 0.2 & 0.5 & 0.001 & $6.68 \pm 0.26$ & 0.21 & 3.2 \\
\hline 26 & 0.5 & 3 & 2 & 1 & 0.01 & $6.57 \pm 0.24$ & 0.10 & 1.6 \\
\hline
\end{tabular}

number of cells of microorganisms by $0.57-1$ billion $/ \mathrm{cm}^{3}$ from the initial titre (Table. 1 ).

In course of studies the dynamics of $R$. $r a-$ diobacter 204 growth was analysed under the action of studied compounds. It was found that under the action of the complex of microelements in culture medium, which most positively impacts $R$. radiobacter 204 growth activity, increase of the duration of exponential growth phase of studied strain by 12 hours is observed that directly affects the increase of bacterial cells (Fig. 6).

Thus, we can conclude the feasibility of nanocarboxylates use for the optimization of 


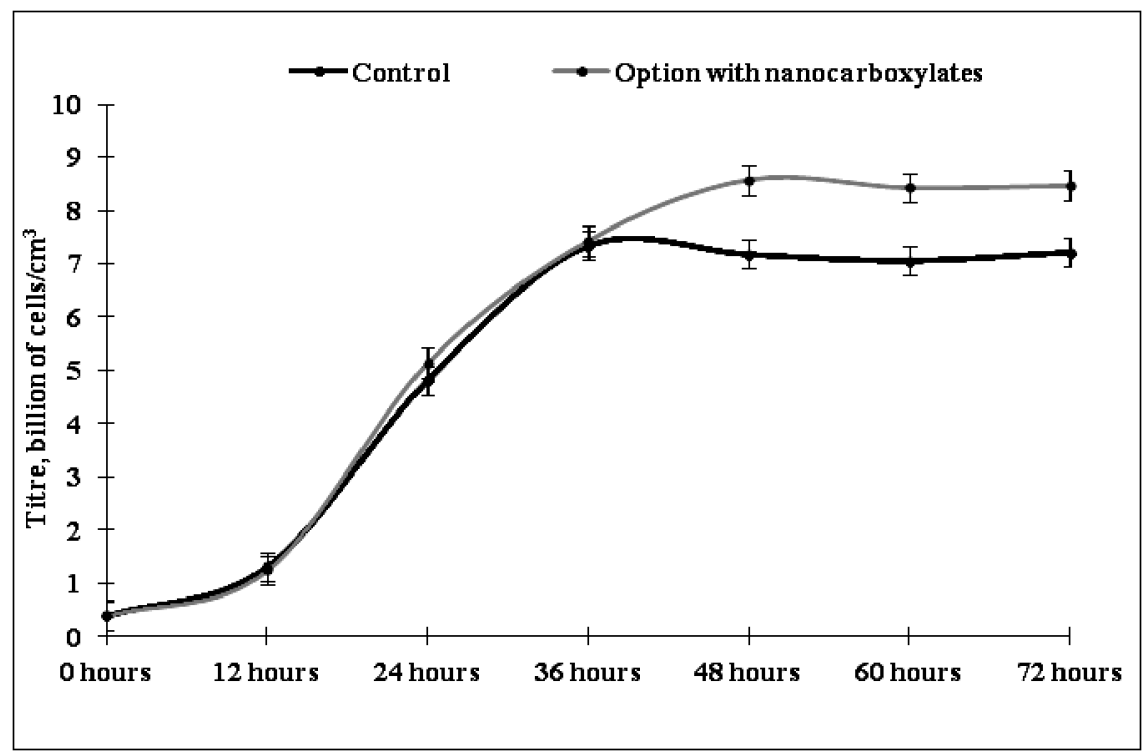

Fig. 6. $R$. radiobacter 204 growth dynamics under the action of nanocarboxylates

culture media for culturing diazotrophs. Complex application of Zinc $(\mathrm{Zn})$, Copper $(\mathrm{Cu})$, Manganese (Mn), Iron (Fe) and Molybdenum (Mo) citrates, obtained with the help of nanotechnology, for culturing $R$. radiobacter 204 allows to increase bacteria titre by 1 billion $/ \mathrm{cm}^{3}$ while increasing the duration of bacteria exponential growth phase.

According to the obtained data we can conclude that $R$. radiobacter 204 bacteria strain is relatively resistant to high concentrations of certain nanocarboxylates contained in the medium, though high content of Zinc (Zn), Manganese $(\mathrm{Mn})$ and Iron $(\mathrm{Fe})$ somewhat inhibits the growth of bacteria. There was no impact of Copper $(\mathrm{Cu})$ and Molybdenum (Mo) on R. radiobacter 204 growth-regulating activity.

1. Готтшалк Г. Метаболизм бактерий / Г. Готтшалк. ; [пер. с англ. Г. П. Мирошниченко, Т. Ю. Перслени]. - М. : Мир, 1982. - 310 с.

2. Гусев М. В. Микробиология : учебник. 2-е изд. / М. В. Гусев, Л. А. Минеева. - М. : Изд. Моск. ун-та, 1985. - $376 \mathrm{c}$.

3. Whitehead D. C. Nutrient elements in grassland, soil-plant-animal relationships / Whitehead, D. C. - New York : CABI Publishing, 2000. $369 \mathrm{p}$.

4. Nyoki D. Influence of Bradyrhizobium japonicum and Phosphorus on micronutrient uptake in cowpea. A case study of Zinc (Zn), Iron (Fe), Copper $(\mathrm{Cu})$ and Manganese $(\mathrm{Mn})$ / D. Nyoki, P. A. Ndakidemi // American journal of plant sciences. - 2014. - № 5. - C. 427-435.

5. Пат. 39397 Україна, МПК С 07 С 51/41, С 07 F 5/00, С 07 F 15/00, С 07 C 53/00. Надчистий водний розчин нанокарбоксилату металу /
Косінов М. В., Каплуненко В. Г. — № U200811445, заявл. 23. 09. 08 ; опубл. 25.02.09, бюл. № 4. $2 \mathrm{c}$.

6. Цитрат цинку, отриманий за аквананотехнологією: хімічна та біологічна характеристика / [М. П. Гуліч, Н. Л. Смченко, Л. А. Томашевська та ін.]. // Environment\&Health. — 2011. — № 2. C. $44-49$.

7. Наноматериалы и нанотехнологии в ветеринарной практике / [В. Б. Борисевич, В. Г. Каплуненко, Н. В. Косинов та ін.]. — К. : Авіцена, 2012. $-512 \mathrm{c}$.

8. Влияние внекорневой обработки микроэлементным комплексом «Аватар 1» на урожайность винограда / Г. А. Прядкина, В. Г. Каплуненко, О. О. Стасик, О. С. Капитанская // Микроэлементы в медицине. — 2014. — № 15(2). C. $40-47$.

9. Пат. 1621433 СССР, МПК С 05 F 11/08, С 12 N 1/20. Штамм бактерий Agrobacterium radiobacter 204 для производства бактериального удобрения под рис и пшеницу / Шерстобоев Н. К., Хотянович А. В., Патыка В. Ф. ; заявитель и патентообладатель Всесоюз. НИИ с.-х. микроб. - № 4487281/13, заявл. 28.09.88 ; опубл. 15.09.90. $-4 \mathrm{c}$.

10. Пат. 38391 Україна, МПК С 07 С 51/41, C 07 F 5/00, C 07 F 15/00, C 07 C 53/126, С 07 C 53/10, А 23 L 1/00, В 82 В 3/00. Спосіб отримання карбоксилатів металів «Нанотехнологія отримання карбоксилатів металів» / Косінов М. В., Каплуненко В. Г. - № U200810939, заявл. 08. 09. 08 ; опубл. 12.01.09, бюл. № 1. $5 \mathrm{c}$.

11. Пат. 43415 Україна, МПК А 61 Р 3/02, А 23 К 1/16, А 61 К 31/205. Спосіб активації метаболічних процесів і підвищення ефективності синтезу білків в живих організмах «Комплексний біофізично-біохімічний наностимулювальний 
ефект Борисевича - Каплуненка - Косінова»/ Борисевич В. Б., Каплуненко В. Г., Косінов М. В. - № U20090361, заявл. 22.04.09 ; опубл. 10.08.09, бюл. № 15. - 6 с.

12. Пат. 44662 Україна, МПК (2009) С 12 N 1/20, 1/32, В 82 В 3/00. Наномодифіковане живильне середовище «Борисевича - Каплуненка Косінова» / Борисевич В. Б., Каплуненко В. Г., Косінов М. В. — U 200904424, заявл. 05.05.09 ; опубл. 12.10.09, бюл. № 19. - 5 с.

13. Хотянович А. В. Методы культивирова-

\section{ВПЛИВ НАНОКАРБОКСИЛАТІВ МІКРОЕЛЕМЕНТІВ НА РОСТОВУ АКТИВНІСТЬ RHIZOBIUM RADIOBACTER 204}

\section{С. Ф. Козар ${ }^{1}$, С. П. Симоненко ${ }^{1}$, В. О. Линник ${ }^{2}$ В. Г. Каплуненко}

${ }^{1}$ Інститут сільськогосподарської мікробіології та агропромислового виробництва НААН, м. Чернігів

${ }^{2}$ Український державний науково-дослідний інститут нанобіотехнологій та ресурсозбереження, м. Київ

Представлено результати досліджень впливу нанокарбоксилатів (иитратів) мікроелементів на ростову активність Rhizobium radiobacter 204. Виявлено, щзо підвищення ростової активності бактерій досягається за вмісту в живильному середовищі ичитратів Цинку (Zn), Купруму (Сu), Мангану (Mn), Феруму (Fe) та Молібдену (Mo) в комплексі. Показано, що застосування нанокарбоксилатів мікроелементів при культивуванні досліджуваного штаму сприяє підвищенню на 1 млрд./см ${ }^{3}$ титру клітин бактерій у рідкому живильному середовищі. Виявлено, щзо культивування $R$. radiobacter 204 за дії ичитратів мікроелементів сприяє подовженню тривалості експоненційної фази росту изих бактерій на 12 годин. За результатами досліджень запропоновано оптимізоване рідке живильне середовище для культивування бактерій.

Ключові слова: Rhizobium radiobacter 204, нанокарбоксилати мікроелементів, цитрати металів, середовище, культивування, оптимізація. ния азотфиксирующих бактерий, способы получения и применения препаратов на их основе : [методические рекомендации] / А. В. Хотянович. - Л. : ВНИИСХМ, 1991. - 54 с.

14. Руководство к практичесикм занятиям по микробиологии : [учеб. пособие] / под. ред. Е. Н. Егорова. - М. : МГУ, 1995. - С. 117-122.

15. Бирюков В. В. Оптимизация периодических процессов микробиологического синтеза / В. В. Бирюков, В. М. Кантере. - М. : Наука, 1985. - $192 \mathrm{c}$.

\section{ВЛИЯНИЕ НАНОКАРБОКСИЛАТОВ МИКРОЭЛЕМЕНТОВ НА РОСТОВУЮ АКТИВНОСТЬ RHIZOBIUM RADIOBACTER 204}

\section{С. Ф. Козар ${ }^{1}$, Е. П. Симоненко ${ }^{1}$, В. О. Линник ${ }^{2}$, В. Г. Каплуненко}

${ }^{1}$ Институт сельскохозяйственной микробиологии и агропромышленного производства НААН, г. Чернигов

${ }^{2}$ Украинский государственный научноисследовательский институт нанобиотехнологий и ресурсозбережения, г. Киев

Представлень результать исследований по изучению влияния нанокарбоксилатов (цитратов) микроэлементов на ростовую активность Rhizobium radiobacter 204. Bblявлено, что повышение ростовой активности бактерий достигается при содержании ичттратов Цинка (Zn), Меди (Cu), Марганйа $(\mathrm{Mn})$, Железа $(\mathrm{Fe})$ и Молибдена (Mo) в питательной среде в комплексе. Показано, что применение нанокарбоксилатив микроэлементов при культивировании исследуемого штамма способствует повышению титра клеток бактерий в жидкой питательной среде на 1 млрд./см ${ }^{3}$. Обнаружено, что культивирование $R$. radiobacter 204 под действием иитратов микроэлементов способствует продлению продолжительности экспоненциальной фазы роста этих бактерий на 12 часов. По результатам исследований предложена оптимизированная жидкая питательная среда для культивирования бактерий.

Ключевые слова: Rhizobium radiobacter 204, нанокарбоксилаты микроэлементов, циитраты металлов, среда, культивирование, оптимизачия. 